\title{
DEVELOPMENT PROSPECTS OF LONDON AS THE WORLD'S FINANCIAL CENTER IN THE CONDITIONS OF BREXIT
}

\author{
Zhanna SYDOROVA', Sergey YAKUBOVSKIY² \\ Odessa I.I. Mechnikov National University, Ukraine
}

\begin{abstract}
The purpose of the study is to examine the role of London as the global financial center in the modern international financial system under the conditions of Britain's withdrawal from the European Union. Methodology. During the study, the comparative method, methods of statistics and economic-mathematical modeling were used. The methodological and theoretical basis of the study is the fundamental provisions of international economic relations, the study of economists in the field of international monetary and financial relations. Information basis is analytical reports of international financial centers and statistical databases of international organizations. Results. Nowadays, London has all the necessary factors for success: open economy, developed financial infrastructure, stability of taxation system, geographical location, long-term government support, transparent policy, investor diversity and multi-culture. It is revealed that a growing variety of financial instruments is a characteristic feature of London as a modern global financial center. As a result, London is gradually winning the battle for the title of the world's leading financial center. The Government of the United Kingdom constantly develops growth strategies of the City of London, creates favorable conditions for the work of international companies, and attracts highly qualified specialists from other countries in the field of finance and law. The competent policy of the state and the wide range of services provided for the successful transactions on stock exchanges and commodity markets help London to maintain undisputed leadership in the global financial market and minimize losses associated with Brexit. At the same time, the decision of the UK to withdraw from the EU had a negative impact on the stability of the country's banking system, it had provoked a decline in the country's credit ratings, a drop in the pound sterling against the dollar and the euro. Another problem for the City of London was the speculation around the loss of multinational companies that might prefer Frankfurt, after the completion of the UK's exit from the EU. Regression analysis revealed that the FTSE 100 index is influenced by such indicators: the industrial production index, the short-term interest rate and the money supply. It was revealed that the current stability of the UK financial system is related to the yield of government securities: a decrease in yield leads to an increase in the stability of the financial system. Practical implications. The study showed that London still remains the most significant financial center in the world, despite concerns about the massive loss of investors and capital as a result of Brexit. In the future, one can expect a strengthening of the pound sterling and higher policy of the Bank of England than in the euro zone, increase of interest rates and a reduction in the tax rates, due to the final withdrawal from the EU, the UK government will no longer have to meet the Maastricht criteria. On the other hand, the UK is not going to enter the EU Banking Union, which will maintain a fairly high level of liberalization in the country's banking system. All this, in turn, will make London even more attractive for national and foreign investors. Value. The role and place of London in the modern global economy and the interest of investors from different countries in the City of London determine the value of this research in the context of the current development of the global financial market and the possible consequences of Brexit, which in the long run are mostly positive.
\end{abstract}

Key words: international financial center, United Kingdom, City of London, economic development, financial market indicators, Brexit.

JEL Classification: E44, F53, G15, O16

\footnotetext{
Corresponding author:

${ }^{1}$ Department of World Economy and International Economic Relations, Odessa I.I. Mechnikov National University.

E-mail: zhanna.sydorova@gmail.com

${ }^{2}$ Department of World Economy and International Economic Relations, Odessa I.I. Mechnikov National University.

E-mail: sergey_yakubovskiy@yahoo.com
} 


\section{Introduction}

The role and place of the global financial centers (GFC) in the modern global economy and the interest of countries in the development of their financial markets determine the relevance of their research in the context of the current development of the international financial environment. The importance of London as the GFC in the world arena and the popularity of the City of London among investors from different countries explain the relevance of this work in the context of the transformation of the global financial market and the possible consequences of Brexit for the UK economy.

Among the foreign scientific works that made a significant contribution to this area, should highlight the studies of P. Buckley, A. Cairncross, G. Cassel, J. Dunning, M. Friedman, J. Keynes, J. Mirkin, J. Sachs, J. Stiglitz, etc. Among the national scientists who deal with this problem, it should be noted A. Filippenko, V. Korneev, I. Lomachynska, L. Shpak, S. Tsyganov, and others. Defining the theoretical and practical value of these studies, a number of questions on the selected problem still require further consideration.

The purpose of the study is to examine the role of London as a global financial center in the modern global financial system in the conditions of Britain's withdrawal from the European Union as a result of Brexit. The achievement of the goal includes the following tasks: to consider the prerequisites for the formation and development of the GFC in London; to estimate London's position in the world ranking of financial centers; to study the influence of the global financial center on the development of the financial market; estimate the problems and influence of Brexit on the UK economy.

During the study, the comparative method, methods of statistics and economic-mathematical modeling were used. Information basis is analytical reports of international financial centers and statistical databases of international organizations.

\section{London as the world's financial center}

London belongs to the historical GFC, ahead of many European cities became the center of world trade and moved to active development of services. This happened in the early 50's, due to the following factors:

1) the position of the former capital of the British Empire allowed to maintain close relations with the United States and Asian countries (the central geographical position contributes to the fact that London is a "bridge" between these regions);

2) the British legal system is the benchmark for international transactions;

3) English became the main language of international business communication;

4) relatively low taxes and a favorable business environment (Nikitina, Repeta-Tursunova, 2014).
Nowadays, the City of London has all the necessary factors for successful operation: open economy, developed financial and transport infrastructure, stability of taxation system, geographical location, transparent state policy, diversity of investors, multiculture, reputation, transparent business environment and openness to external cultures and countries. That is why London has branches of the largest companies (more than 100 of the 500 largest companies in the world have their headquarters in the City of London). The London Stock Exchange (LSE) is the third largest stock exchange by capitalization in the world, it was founded over 200 years ago. The LSE determines the quotations of the entire Old World, showing its independence from American trading platforms. A lot of tools used in the exchange business, appeared right here. Currently, the capitalization of companies traded on the London Stock Exchange exceeds 6 trillion US dollars (Kravets, 2014). According to the World Federation of Exchanges (WFE), in 2016, the London Stock Exchange took the third place in the world in terms of capitalization, reaching the value of 6.18 trillion US dollars, which is $50 \%$ higher than in 2012. Figure 1. shows the market capitalization of companies registered on the London Stock Exchange, by industry.

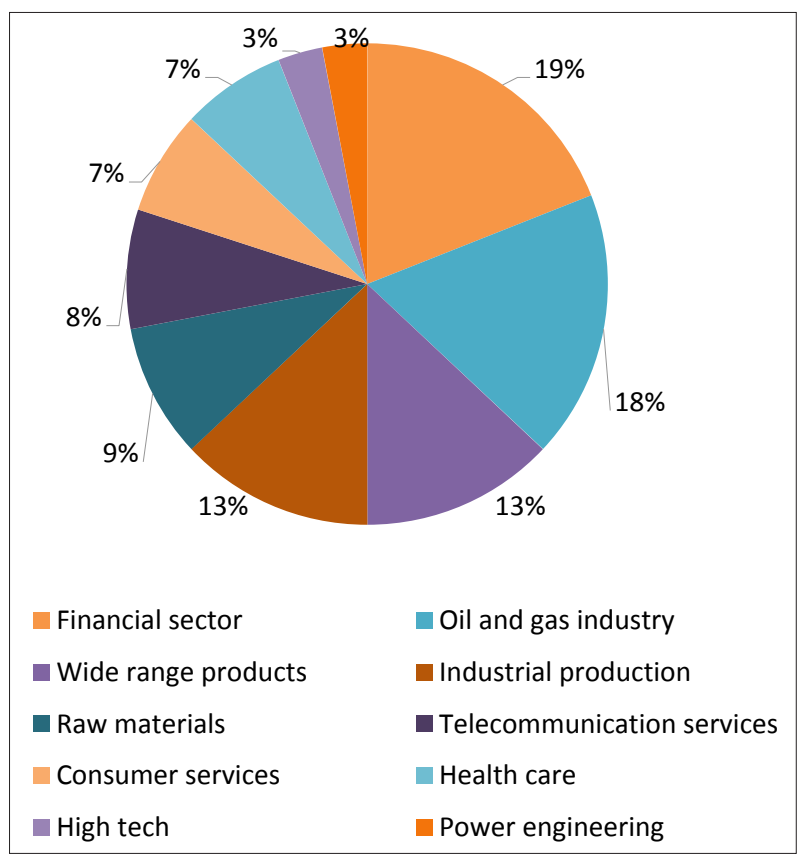

Fig. 1. Market capitalization of companies registered on the London Stock Exchange, by industry

Source: compiled by the author on the basis of (Kravets, 2014)

An important function of the LSE is the definition of the FTSE (Financial Times Stock Exchange Index), which is conducted with the Financial Times. The most famous index traded on the LSE is FTSE 100 - the main stock exchange index, the international symbol of the British stock market, the 
indicator of the success of the UK economy. FTSE 100 is based on the shares of 100 companies with the largest capitalization. The share of these companies occupies most of the capitalization of the LSE. The top five companies in terms of capitalization and liquidity include a mining company, two financial corporations, an oil and gas company and a mobile operator. Thus, it can be concluded that due to its advantages, London is gradually winning the title of the world's leading financial center.

\section{Characteristics of London based on the GFCI index criteria}

To characterize London as GFC, the Global Financial Centers Index (GFCI) was considered, which has been published every year since 2007 by Z/Yen Group. This index is based on five key criteria for the competitiveness of the financial center:

1) «People» - the availability of good personnel and the flexibility of the labour markets;

2) «Business Environment» - regulation, tax rates, levels of corruption and ease of doing business. Regulation is currently cited as the decisive factor in the relative competitiveness of London and New York; 3) «Market Access» - levels of trading, as well as clustering effects from having many financial services firms together in one centre;

4) «Infrastructure» - the cost and availability of property and transport links;

5) «General Competitiveness» - the concept that the whole is "greater than the sum of the parts" (Mainelli, 2007).

In Figure 2, one can consider the dynamics of the GFCI index change, starting from GFCI 1 to GFCI 22. In the GFCI study, starting from the 18th edition, the leading center estimates are considered in dynamics, this allows to determine how the center moves, whether it retains its position, strengthens or loses it. It should be noted that London's rating position began to decline from the time of the world financial crisis in 2008, while the Asian GFCs began to strengthen their position (Lomachynska, 2015).

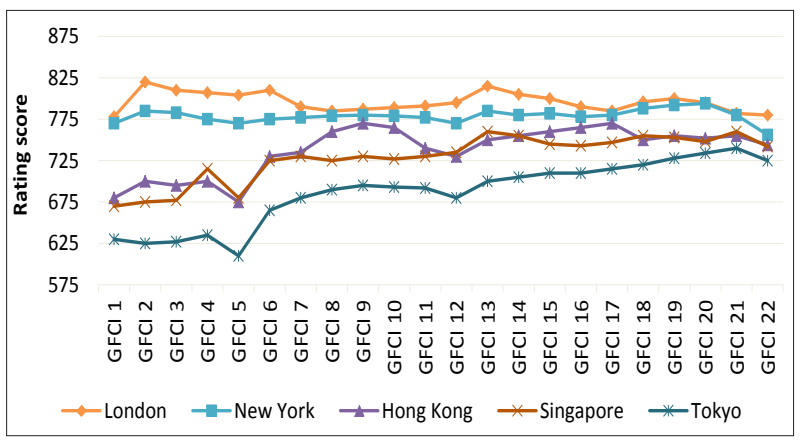

Fig. 2. Top Five Centers - GFCI Ratings Over Time

Source: compiled by the author on the basis of (Yeandle, 2017)
The City of London, according to data for 2017, more than $80 \%$ corresponds to the five main criteria for the competitiveness of GFCI. London achieved this success thanks to its multi-culture (about $40 \%$ of Londoners are foreigners and speak 300 languages). The highest marks were awarded to the qualification of the labor force and its accessibility, flexibility of the labor market and the quality of education. GFCI 22 noted the high level of development of the business environment, but there were also negative comments regarding corporate tax rates, transport infrastructure and operating expenses. The importance and reputation of London as the GFC are growing, but Brexit still causes some uncertainty among investors. It should be noted that in 2017, London overtook New York in the rating and once again became the leader among the world financial centers since the time of the British Empire. Considering London based on the GFCI index criteria, it is necessary to take into account the disadvantages and possible obstacles (such as Brexit) for its further development. For example, the drawbacks of London include: high profit tax rates in comparison with the Asian financial centers and a slowdown in the development of the social sphere due to high direct and indirect costs. At the same time, despite the forced intensification of measures to control the movement of capital, in the fight against the financing of terrorism, restrictive measures, as well as the level of government intervention in the financial sphere in the UK, are still substantially lower than in the rest of the EU (Yakubovskiy, Rodionova, 2014).

\section{Brexit: problems and prospects}

The referendum on the withdrawal of the country from the European Union took place on June 23, 2016. First and foremost, it had a negative impact on the stability of the UK banking system. The decision to withdraw the UK from the EU triggered a decline in the country's credit ratings, a drop in the pound against the dollar and the euro. In June 2016, the pound sterling rate against the dollar declined by $20 \%$, which is the lowest value for the last 30 years. It should be noted the decline in London's position in the GFC rating by two points, compared with last year, but this is a minor loss compared to the losses of other leaders. So, for example, the USA lost 24 rating points due to fears of investors towards the trade policy of President Trump. Another problem for London is the speculation around the loss of multinational companies, which may prefer Frankfurt, after the completion of the UK's exit from the EU. Only within one year Frankfurt rose by 12 points in the ranking and took 11th place. According to many economists, there are all the necessary resources and conditions in Frankfurt to become a good alternative to London. Some companies have already announced their retirement from the City of London. So, Bank of America chose Dublin for a number of its financial 
operations, JP Morgan Chase purchased offices in the central districts of Dublin, and Morgan Stanley has already chosen Frankfurt as an alternative to London.

It should be noted that the Bank of England has eased monetary policy to support the British economy in the Brexit process. For the first time since 2009, the refinancing rate dropped by a quarter of a percent. Now it is at the lowest level for the three-century history of the organization $-0.25 \%$ per annum. The Bank of England, unlike the European Central Bank, is trying to adhere to a more flexible policy in the conduct of monetary policy and is ready to promptly change the discount rate based on the situation in the economy and the financial sector. The ECB has set the refinancing rate at zero mark since 2016 (at the same time it buys assets and bonds for 80 billion euros a month). In the world was 380 billion US dollars more bonds with negative returns, after the decision of the UK to withdraw from the EU. Currently, the yield of 10-year US bonds is at 2,35\% and the yield of 10 -year UK bonds at $1,31 \%$ (Finch, 2017). At the same time, the yield of similar German bonds is lower than English bonds by more than three times, which, accordingly, increases the demand for UK financial assets. Thus, we can conclude that the prospects are positive, London still remains the most significant financial center in the world, despite fears of a massive loss of investors and capital due to Brexit. In the future, we can expect a decrease in the level of taxes, which in turn will make London even more attractive for investors.

Also, one should expect the strengthening of the pound sterling against the euro due to a policy of higher interest rates than in the euro area and a reduction in the tax rates. This is due to the fact that after the final withdrawal from the EU, the UK government will no longer have to meet the Maastricht criteria. At the same time, the UK will not impose new restrictions on banking, which are likely to emerge in the EU after the creation of the Banking Union, which will increase London's attractiveness for banks from EU countries and, possibly, from the US and Asian countries.

\section{The impact of the City of London on the economic development}

The UK stock market, formed at the end of the 18th century, is one of the oldest in the world and according to data for 2017 ranks first in terms of market capitalization in Europe. The London Stock Exchange (LSE) takes the leading position in the stock market. Nowadays, it is one of the most significant and international trading platforms in the world. The stock market of the London Stock Exchange is divided into two segments: the main and alternative markets. The most famous index is the FTSE (the Financial Times Stock Exchange Index) 100, which includes the shares of the 100 largest UK companies on the British stock market (Shamraev, 2014). The market value of shares included in the FTSE 100 index is about $70 \%$ of the total capitalization of the UK.

It will be relevant to analyze the influence of London as a global financial center on the economic development of United Kingdom. The impact of the City of London on the economic welfare of United Kingdom can be assessed using regression analysis. Constructing the regression model, the following indicators were selected: Industrial Production Index (IP), Consumer Price Index (CPI), Interest Rate (IR), Money Supply (MS) and Exchange Rate GBP/USD (ExR). The values of these indicators for the UK were taken from the statistical database on a quarterly basis (The World Bank, 2017). To make more detailed analysis and obtain more reliable results in the regression model, the total time interval covers the period from 2006 to 2016 . The quarterly yield data of the FTSE 100 Index was used as a dependent variable.

The following model was obtained with the probable dependence:

FTSE 100 Index $=\beta 1^{*} \mathrm{IR}+\beta 2^{*} \mathrm{CPI}+$

$$
+\beta 3^{*} \mathrm{IP}+\beta 4^{*} \mathrm{ExR}+\beta 5^{*} \mathrm{MS} \text {. }
$$

After the analysis in SPSS, we can conclude that in this case the multiple correlation coefficient of the model is 0,926 , the explained variable has a strong dependence on the selected set of predictors. The R-square is 0,857 , which means that $86 \%$ of the selected factors explain the dependent variable and $14 \%$ of the variance is unaccounted factors. For this model, Fst $>$ Fcr (Fst $=72,026)$. With 95\% probability this model can be considered significant. The results of standardized coefficients allow us to identify which factors have the greatest influence on the dependent variable. The analysis revealed a low value of tst of the two indicators, which led to their removal from the model. The model coefficients (IP, CPI, MS) are significant, each of these variables explains the selected dependent parameter FTSE 100 Index by more than 90\%. Among the standardized beta coefficients the greatest influence is exerted by the coefficient 0,489 (the industrial production index). With an increase in this factor by 1 tbsp. deviation, the dependent variable will decrease by 0,489 . Less influence has the short-term interest rate and the money supply. All coefficients are significant at the level of $1 \%$ (all tst $>$ tcr).

The obtained model has the form:

FTSE 100 Index =0,489 IP-0,237 CPI-0,564MS. (2)

The current moment of stability and development of the financial system of United Kingdom can be analyzed by such an indicator as the yield of government securities. With a decrease in the yield of government securities, one can talk about improving the stability of the country's financial system. The level of return on long-term bonds issued by the government of the United Kingdom over the past 20 years has gradually declined. 
Therefore, for further analysis, we will construct a regression model of the dependence of the level of profitability of long-term government bonds (GB) and Inflation Rate (Inf), Interest Rate (IR), Government Debt (GD), Money Supply (MS) and Exchange Rate GBP/USD (ExR) (The World Bank, 2017). The time interval covers the period from 1996 to 2016.

As a result, the following model was obtained with the probable dependence:

$$
\mathrm{GB}=\beta 1^{*} \operatorname{Inf}+\beta 2^{*} \mathrm{IR}+\beta 3^{*} \mathrm{GD}+\beta 4^{*} \mathrm{MS}+\beta 5^{*} \mathrm{ExR} \text {. (3) }
$$

After the analysis in SPSS, we can conclude that in this case the coefficient of determination (R-square) is 0,906 , which means that the yield level of long-term government bonds is $90 \%$ described by the selected indicators. Based on the data obtained in the analysis, it should be noted that for this model $\mathrm{F}_{\mathrm{st}}>\mathrm{F}_{\mathrm{cr}}$ since $\mathrm{F}_{\mathrm{st}}=43,223$. With $95 \%$ probability this model can be considered significant. The analysis revealed a low value of $t_{s t}$ of one of the indicators, which led to its removal from the model. The coefficients of the model (Inf, IR, GD, MS) are significant, each of these variables explains the selected dependent GB parameter by more than $90 \%$. Based on the standardized beta coefficients, we can draw the following conclusions that among the coefficients the coefficient of 0,506 (interest rate) has a greater impact. With an increase in this factor by $1 \mathrm{tbsp}$. deviation, the dependent variable will decrease by 0,506 . Less influence has the volume of the money supply, the inflation rate and government debt. All coefficients are significant at the level of $1 \%\left(\right.$ all $t_{\mathrm{st}}>\mathrm{t}_{\mathrm{cr}}$ ).

The obtained model has the form:

$$
\mathrm{FS}=0,358 \mathrm{Inf}+0,506 \mathrm{IR}+0,025 \mathrm{GD}-0,412 \mathrm{MS} \text {. (4) }
$$

By the results of regression analysis, we can conclude that there is an inverse relationship between the dynamics of changes in the inflation rate and the dynamics of changes in the yield of long-term government bonds. That is, the higher the inflation rate, the higher the yield of government securities, which means that the financial sector is less stable. A high inflation rate with a strong pound sterling against the dollar leads to a greater consumption of foreign goods, that is, to an increase in imports and to restrain exports, which adversely affects the trade balance and the current account. In turn, the higher the inflation rate, the lower the stability of the financial sector, since high inflationary risks appear. There is also an inverse relationship between the dynamics of changes in government debt and the yield of government bonds. The higher the public debt, the more funds the state needs to attract for its repayment, the greater the yield of government-issued debt securities. This, in turn, negatively affects the level of sustainability and development of the country's financial system.

\section{Conclusions}

The studies in this paper allow us to make the following conclusions. A characteristic feature of London as a global financial center, at the present stage of development, is the growing diversity of financial instruments. Nowadays, London has all the necessary factors for success: open economy, financial infrastructure, stability of taxation, geographical location, long-term government support, transparent policy, investor diversity and multi-culture. Due to its liberal legislation, London is gradually winning the title of the world's leading financial center. The Government of the United Kingdom on an ongoing basis develops growth strategy of the City of London, creates favorable conditions for the work of international companies, and attracts highly qualified specialists in finance and law. The competent policy of the state and the wide range of services, that are required for the successful transactions on stock exchanges and commodity markets, help London to retain undisputed leadership in the global financial market and minimize losses associated with Brexit.

The analysis of UK stock indices based on the regression model revealed that the index of the FTSE 100 is influenced by such indicators as the industrial production index, the short-term interest rate and the money supply. The current stability of the financial system of the United Kingdom, according to studies, is related to the yield of government securities, the decrease in profitability of which leads to the stabilization of the financial system and its sustainability. It can be concluded that the prospects are positive, London still remains the most significant financial center in the world, despite fears of a massive loss of investors and capital due to Brexit. In the future, one can expect the strengthening of the pound sterling, the influx of investments into British securities, the reduction of the level of taxes and the changes in the state liberal policy over the financial market control, which will become especially noticeable in the EU countries as a result of the creation of the Banking Union.

\section{References:}

Finch, G. (2017, September 11). London Retains Its Crown as World's Top Financial Center. Bloomberg. Retrieved from: https://www.bloomberg.com

Kravets, F. (2014). LSE - London Stock Exchange - in details. Equity. Retrieved from: https://equity.today

Lomachynska I. A. (2015). Finansovi systemy krayin Pivdenno-Skhidnoyi ta Skhidnoyi Aziyi: osoblyvosti suchasnoho rozvytku [Financial Systems of the South and East Asian Countries: Features of Contemporary Development]. Scientific Journal of Uzhgorod National University. International economic relations and world economy, №2, 11-15. 
Mainelli M. (2007). Market of Markets: The Global Financial Centres Index. Journal of Risk Finance, 8(3), 313-319. Nikitina, T. V., \& Repeta-Tursunova, A. V. (2014). Financial Markets and Financial Institutions. St. Petersburg: SPbGEU.

Shamraev, A. (2014). International and Foreign Financial Regulation: Institutions, Transactions, Infrastructure. Moscow: Knorus.

The World Bank Data (2017). United Kingdom. Retrieved from: https://data.worldbank.org/country/unitedkingdom?view=chart

Yakubovskiy, S. O., \& Rodionova, T. A. (2014). International Experience of the Foreign Capital Control Measures and the Ways to Implement it in Ukraine. Actual Problems of International Relations, Vol. 2, № 121. Retrieved from: http://journals.iir.kiev.ua/index.php/apmv/article/download/2401/2134

Yeandle, M. (2017, September). The Global Financial Centres Index 22. Z/Yen Group and the China Development Institute, 22, 48.

\section{Жанна СИДОРОВА, Сергей ЯКУБОВСКИЙ}

\section{ПЕРСПЕКТИВЫ РАЗВИТИЯ ЛОНДОНА}

\section{В УСЛОВИЯХ БРЕКСИТА}

Аннотация. Целью работы является исследование роли Лондона как мирового финансового центра в современной мировой финансовой системе в условиях выхода Великобритании из Евросоюза. Методика. При написании работы были использованы сравнительный метод, методы статистики и экономико-математического моделирования. Методологической и теоретической базой исследования являются фундаментальные положениямеждународныхэкономическихотношений, работыученых-экономистов вобластимеждународных валютно-финансовых отношений. Информационной основой являются аналитические отчеты международных финансовыхцентровистатистическиебазыданныхмеждународныхорганизаций.Результаты. Насегодняшний день Лондон располагает всеми необходимыми факторами успеха: открытая экономика, развитая финансовая инфраструктура, стабильность налогообложения, географическое положение, долгосрочная поддержка государства, прозрачная политика, разнообразие инвесторов и мульти-культура. Выявлено, что характерной чертой Лондона как современного мирового финансового центра является растущее многообразие финансовых инструментов. В результате Лондон постепенно побеждает в схватке за звание ведущего мирового финансового центра. Правительство Великобритании на постоянной основе разрабатывает стратегии развития Лондонского Сити, создает выгодные условия для работы международных компаний, а также привлекает высококвалифицированных специалистов из других стран в сфере финансов и права. Именно грамотная политика государства и широкий спектр предоставляемых услуг, необходимых для успешного заключения сделок на фондовых биржах и сырьевых рынках, помогают Лондону удерживать бесспорное лидерство на мировом финансовом рынке и минимизировать потери, связанные с Брекситом. В тоже время решение о выходе Великобритании из ЕС оказало негативное влияние на устойчивость банковской системы страны, спровоцировало снижение кредитных рейтингов страны, падение фунта стерлинга по отношению к доллару и евро. Еще одной проблемой для Лондонского Сити стали спекуляции вокруг потери крупных компаний, которые возможно отдадут предпочтение Франкфурту, после завершения процедуры выхода Великобритании из ЕС. На основе регрессионного анализа выявлено, что на индекс FTSE 100 оказывают влияние такие показатели: индекс промышленного производства, краткосрочная процентная ставка и количество денег в обращении. Выявлено, что текущая стабильность финансовой системы Великобритании связана с доходностью государственных ценных бумаг: снижение доходности приводит к повышению устойчивости финансовой системы. Практическое значение. Исследование показало, что Лондон по прежнему остается самым значимым финансовым центром в мире, несмотря на опасения относительно массовой потери инвесторов и капитала в результате Брексита. В перспективе можно ожидать укрепления фунта стерлингов, политику более высоких, чем в зоне евро, процентных ставок со стороны Банка Англии, а также снижения уровня налогов, так как после окончательного выхода из ЕС правительству Великобритании уже не будет необходимости соответствовать Маастрихтским критериям. С другой стороны Великобритания точно не войдет в Банковский союз ЕС, что сохранит в банковской системе страны достаточно высокий уровень либерализации. Все это, в свою очередь, сделает Лондон еще более привлекательным для национальных и иностранных инвесторов. Значение. Роль и место Лондона в современном мировом хозяйстве и заинтересованность инвесторов из разных стран в Лондонском Сити обуславливает ценность этого исследования в контексте современного развития мирового финансового рынка и возможных последствий Брексита, которые в долгосрочной перспективе большей частью являются положительными. 